\title{
Ribotype Delineation and Description of Staphylococcus sciuri Subspecies and Their Potential as Reservoirs of Methicillin Resistance and Staphylolytic Enzyme Genes
}

\author{
WESLEY E. KLOOS, ${ }^{1}$ DEBORAH N. BALLARD, ${ }^{1}$ JOHN A. WEBSTER, ${ }^{2 *}$ ROMEO J. HUBNER, ${ }^{2}$ \\ ALEXANDER TOMASZ, ${ }^{3}$ ISABEL COUTO,${ }^{3}$ GARY L. SLOAN,${ }^{4}$ HEATHER P. DEHART,${ }^{4}$ \\ FRANZ FIEDLER, ${ }^{5}$ KARIN SCHUBERT, ${ }^{5}$ HERMINIA DE LENCASTRE, ${ }^{3}$ \\ ILDA SANTOS SANCHES, ${ }^{3}$ HARRY E. HEATH ${ }^{4}$ \\ PAUL A. LEBLANC, ${ }^{4}$ AND ÅSA LJUNGH ${ }^{6}$ \\ North Carolina State University, Raleigh, North Carolina 27695-7614 ${ }^{1}$; Qualicon, L. L. C., Wilmington, \\ Delaware 19880-0402²; The Rockefeller University, New York, New York 10021-63993; \\ University of Alabama, Tuscaloosa, Alabama 35487-03344; University of Munich, \\ Munich, Germany; and Lund University, Lund S-223 62, Sweden ${ }^{6}$
}

\begin{abstract}
Three subspecies of Staphylococcus sciuri, S. sciuri subsp. sciuri Kloos, Schleifer, and Smith 1976, $23^{\mathrm{AL}}$ emend. Kloos et al. 1996, $S$. sciuri subsp. carnaticus subsp. nov., and $S$. sciuri subsp. rodentium subsp. nov., are described on the basis of their ribotype patterns, DNA-DNA liquid hybridization data, and phenotypic characteristics. Normalized ribotyping subdivided the $S$. sciuri patterns into three blocks of patterns, each corresponding to a subspecies. Each subspecies formed a separate, well-defined DNA similarity group when DNA-DNA hybridizations were conducted under stringent $\left(70^{\circ} \mathrm{C}\right)$ reassociation conditions. $S$. sciuri subsp. sciuri could be distinguished from the other subspecies on the basis of its ability to produce acid from D-cellobiose, alkaline phosphatase activity, and inability to produce either clumping factor or protein A. S. sciuri subsp. carnaticus could be distinguished by its ability to produce acid aerobically from D-xylose and maltose, inability to produce acid from D-melezitose, and smaller colony size on $\mathrm{P}$ agar. $S$. sciuri subsp. rodentium could be distinguished by its positive reaction in the latex agglutination test for clumping factor and/or protein $A$ and generally higher frequencies and levels of oxacillin and methicillin resistance. All 40 strains of $S$. sciuri tested (including representatives of all three subspecies) hybridized with the mecA gene probe. All strains of $S$. sciuri subsp. sciuri, 79\% of the strains of $S$. sciuri subsp. carnaticus and $89 \%$ of the strains of $S$. sciuri subsp. rodentium exhibited extracellular, staphylolytic enzyme activity. This activity was associated with an enzyme(s) that immunoblotted with a lysostaphin-specific monoclonal antibody; however, only three strains hybridized with a lysostaphin (end) gene probe. The type strain of $S$. sciuri subsp. carnaticus is DD 791 (= ATCC 700058), and the type strain of $S$. sciuri subsp. rodentium is DD 4761 (= ATCC 700061).
\end{abstract}

Staphylococcus sciuri is generally considered one of the most primitive Staphylococcus species; it is widely distributed in nature, is capable of growth on inorganic nitrogen salts as the sole source of nitrogen, and exhibits a wide range of biochemical activities (31-33). In the past 20 years since its original description (33), numerous laboratories have reported frequent isolation of this species from foods, farm animals, rodents, marsupials, marine mammals, and birds and occasional isolation from humans and their pets $(1,2,17,28,31,35,48,52,57,58)$. Most resident populations of $S$. sciuri are members of the normal cutaneous microflora of lower mammals. This species is rarely associated with infections. A preliminary investigation of a large collection of $S$. sciuri strains showed that a ribotyping method based on an analysis of genomic EcoRI fragments containing portions of the rRNA operons could be used to distinguish two major subgroups and additional strain variation within the species (10).

In this study, we describe three subpopulations of $S$. sciuri which can be distinguished on the basis of their ribotype patterns, DNA-DNA liquid hybridization data, and phenotypic characteristics. Compared to the ribotypes representing the subpopulation of $S$. sciuri subsp. sciuri, the ribotypes representing a second subpopulation appeared to have one region ad-

${ }^{*}$ Corresponding author. Phone: (302) 695-1613. Fax: (302) 6958557. E-mail: WEBSTEJA@A1.ESVAX.UMC.DUPONT.COM. jacent to an rRNA operon replaced in its entirety, while the ribotypes representing a third subpopulation appeared to have two regions adjacent to different rRNA operons replaced in their entirety. Each of these subpopulations has been given subspecies status. In this report, we include an amended description of $S$. sciuri subsp. sciuri (Kloos, Schleifer, and Smith 1976), describe two additional subspecies, $S$. sciuri subsp. carnaticus and $S$. sciuri subsp. rodentium, and designate the type strains of these taxa. The nature of two surprising phenotypic properties, common methicillin resistance and staphylolytic activity, were explored in some detail, because these properties indicate that $S$. sciuri is a natural reservoir of important methicillin resistance and staphylolytic enzyme genes and their products that are novel to certain other Staphylococcus species $(5,21,39,43,53,54)$.

\section{MATERIALS AND METHODS}

Bacterial strains. The designations and sources of the strains used to describe the $S$. sciuri subspecies are listed in Table 1. Unless indicated otherwise, all strains were isolated from the skin of mammalian hosts. Strains from the neonatal ward of the Department of Pediatrics, Maputo Central Hospital, Maputo, Mozambique, were isolated from the umbilici of infants, the teats of mothers, soaps, and the surfaces of incubator entrances.

The methicillin-resistant Staphylococcus aureus strains used as positive controls for the presence of the mecA gene were COL and N315. Strain RN2677, a methicillin-susceptible $S$. aureus strain, was used as a negative control. These strains were obtained from the Rockefeller University culture collection. The Escherichia coli strain containing the plasmid with the $S$. aureus mec $A$ probe has been described previously $(15,38)$. Lysostaphin-producing Staphylococcus simu- 
TABLE 1. S. sciuri strains and their sources

\begin{tabular}{|c|c|c|c|c|}
\hline \multirow{2}{*}{ Subspecies } & \multicolumn{3}{|c|}{ Strain designations } & \multirow{2}{*}{ Source } \\
\hline & DuPont & Kloos & $\mathrm{ATCC}^{a}$ & \\
\hline \multirow[t]{26}{*}{ S. sciuri subsp. sciuri } & $\mathrm{DD} 4277^{\mathrm{T}}$ & $\mathrm{SC} 116^{\mathrm{T}}$ & ATCC $29062^{\mathrm{T}}$ & Eastern gray squirrel \\
\hline & DD 4285 & SC 255 & & Eastern gray squirrel \\
\hline & DD 4287 & SC 114 & & Eastern gray squirrel \\
\hline & DD 4276 & GV 252 & ATCC 29061 & Southern flying squirrel \\
\hline & DD 4289 & GV 212 & & Southern flying squirrel \\
\hline & DD 5277 & MM1b5 & & Eastern harvest mouse \\
\hline & DD 5272 & PC2D5 & & California mouse \\
\hline & DD 5285 & MO2-1 & & Prairie vole \\
\hline & DD 4274 & DM 128 & ATCC 29059 & Opossum \\
\hline & DD 4278 & DM 71 & & Opossum \\
\hline & DD 4279 & DM 81 & & Opossum \\
\hline & DD 4281 & DM 93 & & Opossum \\
\hline & DD 5286 & MR1P2 & & Red kangaroo \\
\hline & DD 4747 & BT 21 & & Beef tongue \\
\hline & DD 4537 & BT 22 & & Beef tongue \\
\hline & DD 4526 & BL 12 & & Beef lips \\
\hline & DD 5262 & CA2L1 & & Jersey cattle calf \\
\hline & DD 5256 & HE1L13 & & Jersey cattle heifer \\
\hline & DD 5748 & H2L 28 & & Morgan horse \\
\hline & DD 4731 & $\mathrm{H} 2 \mathrm{~F} 14$ & & Morgan horse \\
\hline & DD 4520 & $\mathrm{H} 4 \mathrm{~L} 2$ & & Arabian horse \\
\hline & DD 6059 & TT12b3 & & Bottle-nosed dolphin \\
\hline & DD 6044 & TT4m2 & & Bottle-nosed dolphin \\
\hline & DD 6069 & GMWg1 & & Pilot whale \\
\hline & DD 4292 & CF 3 & & Domestic dog \\
\hline & DD 4295 & SS 226 & & Squirrel monkey \\
\hline \multirow[t]{14}{*}{ S. sciuri subsp. carnaticus } & DD $791^{\mathrm{T}}$ & & ATCC $700058^{\mathrm{T}}$ & Veal leg, sliced \\
\hline & DD 792 & & & Veal leg, sliced \\
\hline & DD 4750 & BL 2 & & Beef lips \\
\hline & DD 5666 & CA1F6 & & Jersey cattle calf \\
\hline & DD 5268 & CA1F14 & & Jersey cattle calf \\
\hline & DD 5238 & CA1L9 & & Jersey cattle calf \\
\hline & DD 5254 & HE1L18 & ATCC 700060 & Jersey cattle heifer \\
\hline & DD 5255 & HE1L19 & & Jersey cattle heifer \\
\hline & DD 5248 & HE1F6 & & Jersey cattle heifer \\
\hline & DD 5251 & HE2F4 & & Jersey cattle heifer \\
\hline & DD 4530 & $\mathrm{C} 3 \mathrm{~F} 23$ & & Holstein cattle cow \\
\hline & DD 5234 & B3L6 & & Aberdeen Angus bull \\
\hline & DD 5284 & MP1v1 & & Acouchy (Cavy) \\
\hline & DD 6081 & TT13b1 & ATCC 700059 & Bottle-nosed dolphin \\
\hline \multirow[t]{18}{*}{ S. sciuri subsp. rodentium } & DD $4761^{\mathrm{T}}$ & $\mathrm{R} 1-33^{\mathrm{T}}$ & ATCC $700061^{\mathrm{T}}$ & Norway rat \\
\hline & DD 4535 & $\mathrm{R} 1-12$ & ATCC 700063 & Norway rat \\
\hline & DD 4762 & R1-27 & & Norway rat \\
\hline & DD 4773 & $\mathrm{R} 1-39$ & & Norway rat \\
\hline & DD 4780 & R3-133 & & Norway rat \\
\hline & DD 4776 & R4-151 & & Norway rat \\
\hline & DD 4765 & R4-154 & & Norway rat \\
\hline & DD 4768 & CR5-5 & & Cotton rat \\
\hline & DD 4778 & CR5-249 & & Cotton rat \\
\hline & DD 5283 & SVv1 & & European red squirrel \\
\hline & DD 5282 & SVv6 & & European red squirrel \\
\hline & DD 6077 & GMWg14 & ATCC 700062 & Pilot whale \\
\hline & DD 6272 & MM 2 & & Neonatal ward (Maputo) \\
\hline & DD 6273 & MM 3 & & Neonatal ward (Maputo) \\
\hline & DD 6276 & MM 8 & & Neonatal ward (Maputo) \\
\hline & DD 6278 & MM 11 & & Neonatal ward (Maputo) \\
\hline & DD 6281 & MM 16 & & Neonatal ward (Maputo) \\
\hline & DD 6282 & MM 17 & & Neonatal ward (Maputo) \\
\hline
\end{tabular}

${ }^{a}$ ATCC, American Type Culture Collection, Rockville, Md.

lans biovar staphylolyticus strain NRRL B-2628 (53) was used as a positive control for staphylolytic activity, reactivity with a lysostaphin-specific monoclonal antibody (MAb), and hybridization with a lysostaphin gene (end) probe. The non-lysostaphin-producing and lysis assay organism S. aureus FDA 209P (= ATCC $6538 \mathrm{P}$ ) was used as a negative control.
Phenotypic characterization. The following characteristics were determined as described previously $(29,30,33,59)$ : Gram-stained cell morphology and cell arrangement, colony morphology and pigmentation, motility, anaerobic growth in thioglycolate semisolid medium, catalase activity, acetylmethylcarbinol (acetoin) production, nitrate reduction, oxidase activity, pyrrolidonyl arylamidase 
activity, esculin hydrolysis, thermonuclease activity, ornithine decarboxylase activity, urease activity, staphylocoagulase activity, hemolysis of sheep, bovine, and horse blood, and carbohydrate reactions. The presence of clumping factor and/o protein A was tested by using a Staph Latex kit (Remel, Lenexa, Kans.) and Staph-A-Lex (Trinity Laboratories, Inc., Raleigh, N.C.). Antibiotic susceptibilities were determined by disk diffusion tests involving incubation of cultures on tryptic soy agar (TSA) (Difco Laboratories, Detroit, Mich.), Mueller-Hinton agar, and Mueller-Hinton agar containing $2 \%$ sodium chloride at $35^{\circ} \mathrm{C}$ for $24 \mathrm{~h}$ in the presence of various antibiotic disks, followed by measurement of diameter of zones of inhibition (halos) $(60)$. All three of the media used in these tests produced similar results if they were freshly prepared and stored at $4^{\circ} \mathrm{C}$ for no longer than 1 week prior to use. Colony size, pigmentation, luster, profile, and consistency were determined on plates containing freshly prepared $\mathbf{P}$ agar (32) TSA, and TSA supplemented with $5 \%$ sheep blood following point inoculation, incubation for $72 \mathrm{~h}$ at $35^{\circ} \mathrm{C}$, and storage at room temperature for an additional 2 days $(29,30)$. Alkaline phosphatase, urease, $\beta$-galactosidase, $\beta$-glucosidase, and $\beta$-glucuronidase activities and arginine utilization were tested with the API STAPH-IDENT system (bioMérieux Vitek, Hazelwood, Mo.). Additional biochemical profile data were obtained by using the STAPH Trac and ID32 STAPH systems (bioMérieux Vitek).

The extracellular staphylolytic enzyme activity of selected strains was evaluated by visualizing zones of bacteriolysis following growth on a modified lysostaphin production medium (45) that contained heat-killed cells of $S$. aureus ATCC $6538 \mathrm{P}$, as described previously (46), and by renaturing activity gel analysis (41).

Normalized ribotyping. Discrete and reproducible ribotype descriptions of strains resulted from a single method described previously in detail $(11,24,59)$. Briefly, strains were lysed with staphylolytic enzymes and sodium dodecyl sulfate (SDS). The solution was extracted with phenol and chloroform, and the DNA was precipitated with ethanol. The DNA was digested with EcoRI. The resulting fragments were separated by performing agarose gel electrophoresis in a minigel apparatus. The size-separated fragments were immobilized on a membrane by electrophoretic transfer, denatured, and probed. The $r m B$ ribosomal operon from $E$. coli (9), labeled by sulfonation, was used as a probe. Immobilized fragments selected by hybridization were detected with an antisulfonated DNA MAb conjugated to alkaline phosphatase and a chemiluminescent substrate. The image consisting of lanes of bands on the membrane was captured electronically and recorded. Computerized procedures were used to extract the strain data from each lane and to digitally process the bands to provide a normalized and reproducible characterization. Each strain was then represented in a database by a set of fragment bands. Sets from independently isolated strains that were indistinguishable within the experimental error were averaged, and the average was stored as a ribotype pattern type.

Genomic DNA-DNA hybridization. Unlabeled and $\left[\right.$ methyl- $\left.{ }^{3} \mathrm{H}\right]$ thymidine-labeled total DNAs were isolated and purified by using the procedures of Brenner and coworkers (8), as modified by Kloos and Wolfshohl (34) and optimized for use with $S$. sciuri and other staphylococcal species that are somewhat difficult to lyse. Cultures were grown in tryptic soy broth (Difco) supplemented with glycine (10 to $15 \mathrm{~g} /$ liter) to produce lysis-susceptible cells for DNA isolation. The lysing buffer contained the following ingredients: glucose, $0.9 \mathrm{~g}$; Tris, $0.39 \mathrm{~g}$; EDTA (anhydrous), $0.29 \mathrm{~g}$; chicken egg white lysozyme (Sigma Chemical Co., St. Louis, Mo.), $80 \mathrm{mg}$; Ambicin L (recombinant lysostaphin) (Aplin \& Barrett Ltd., Clarks Mill, Trowbridge, Wilts, United Kingdom), $10 \mathrm{mg}$; and deionized $\mathrm{H}_{2} \mathrm{O}, 100 \mathrm{ml}$. DNA-DNA reassociation reactions were performed under stringent $\left(70^{\circ} \mathrm{C}\right)$ conditions to best identify subspecies populations, although several additional reactions were performed under optimal $\left(55^{\circ} \mathrm{C}\right)$ conditions in order to make comparisons at the species level $(27,28)$. At the termination of reactions, doublestranded (hybridized) DNA was separated from unreacted, single-stranded DNA on hydroxyapatite by the batch procedure described by Brenner and coworkers (8). The relative binding (or DNA relatedness) was determined by normalizing the amount of DNA bound to hydroxyapatite in heterologous reactions to the amount bound in the homologous reaction, in which the labeled and unlabeled DNAs were from the same organism.

Cell wall analysis. Cell walls purified with $4 \%$ SDS by the procedures of Glauner et al. (20) were used to determine peptidoglycan composition and teichoic acid composition. Amino acid and teichoic acid analyses were performed as described previously $(4,26,59)$. The levels of amino acids and amino sugars were determined by using a model LC6001 amino acid analyzer (Biotronik, Maintal, Germany). The peptidoglycan type was determined on the basis of the molar ratios of glutamic acid to L-lysine, to L-serine, to $\mathrm{L}$-alanine, and to glycine (50). The sugar constituents of teichoic acids were determined by gas-liquid chromatography by using a Packard model GC 438 gas chromatograph equipped with a flame ionization detector (Packard Instrument Co., Meriden, Conn.) and a column ( 2 by $1,000 \mathrm{~mm}$ ) filled with $3 \%$ SP 2340 on $100 / 200$ Supelcoport (Supelco, Bellefonte, $\mathrm{Pa}$.), and glycerol was detected enzymatically by the method of Bergmeyer (7). Phosphate levels were determined by the method of Ames (3).

DNA base composition. The guanine-plus-cytosine $(\mathrm{G}+\mathrm{C})$ content of DNA was determined by the thermal denaturation method of Marmur and Doty (37) by using a Guilford Response spectrophotometer with Response II thermal programming (Guilford Systems, Ciba Corning Diagnostics Corp., Oberlin, Ohio).
Dot blot hybridization with the mecA gene probe. Dot blot hybridization was performed as described previously $(16,49)$, with the following modifications. Overnight cultures $(0.4 \mathrm{ml})$ were centrifuged and washed with $1 \mathrm{ml}$ of TrisEDTA buffer (TE). Cell walls were digested by adding $6 \mu l$ of chicken egg white lysozyme $(10 \mathrm{mg} / \mathrm{ml}$ in TE [pH 8.0]; Sigma), $15 \mu$ l of lysostaphin $(10 \mathrm{mg} / \mathrm{ml}$ in TE [pH 8.0]; Sigma), and $100 \mu \mathrm{l}$ of TE ( $\mathrm{pH} 8.0$ ) and incubating the preparation at $37^{\circ} \mathrm{C}$ for $1 \mathrm{~h}$. The resulting protoplasts were lysed with $10 \mu \mathrm{l}$ of $10 \%$ SDS and 2 $\mu l$ of proteinase $\mathrm{K}(10 \mathrm{mg} / \mathrm{ml}$; Boehringer Mannheim Biochemicals, Indianapolis, Ind.) at $37^{\circ} \mathrm{C}$ for $1 \mathrm{~h}$. The lysate was treated with phenol-chloroform-isoamyl alcohol, and the aqueous phase containing DNA was separated by centrifugation and denatured by adding $150 \mu \mathrm{l}$ of $3 \mathrm{M} \mathrm{NaOH}$; this was followed by incubation at room temperature for $15 \mathrm{~min}$. The samples were then chilled at $0^{\circ} \mathrm{C}$, and the $\mathrm{pH}$ was neutralized by adding $150 \mu \mathrm{l}$ of $2 \mathrm{M}$ sodium acetate. After centrifugation at $4^{\circ} \mathrm{C}$, the supernatant fluids were transferred to prechilled tubes. A $25-\mu$ aliquot from each sample was loaded into a dot blot apparatus (Bio-Rad Laboratories, Hercules, Calif.). The DNA probe containing the mecA gene (38) was labeled with ${ }^{32} \mathrm{P}$ by using the Megaprime labeling system (catalog no. RPN1606; Amersham International plc, Little Chalfont, Bucks, United Kingdom) according to the manufacturer's instructions.

Quantitative analysis of staphylolytic enzyme production and lysostaphin susceptibility. A quantitative analysis of staphylolytic enzyme production (activity) in culture supernatants was performed by a standard tube assay for lysostaphin activity in which the lysis of a suspension of cells of S. aureus FDA 209P (optical density at $620 \mathrm{~nm}, 0.250$ ) is monitored spectrophotometrically (44); $1 \mathrm{U}$ of activity was defined as the amount of enzyme that caused a $50 \%$ reduction in turbidity in $10 \mathrm{~min}$ at $37^{\circ} \mathrm{C}$. Quantitative determinations of lysostaphin susceptibility were determined spectrophotometrically as described previously (14) by using a final lysostaphin concentration of $1 \mathrm{U} / \mathrm{ml}$.

Immunological analysis of staphylolytic enzymes. Culture supernatants were tested for reactivity with lysostaphin-specific MAb ALS8.1 (18) by an enzymelinked immunosorbent assay and by immunoblotting. For the enzyme-linked immunosorbent assay, supernatants were mixed with an equal volume of $45 \mathrm{mM}$ sodium carbonate-bicarbonate buffer ( $\mathrm{pH} 9.6$ ) and added to 96-well plates for $2 \mathrm{~h}$ at $37^{\circ} \mathrm{C}$ before blocking with bovine serum albumin $(1 \mathrm{mg} / \mathrm{ml})$ and subsequen exposure to ALS8.1. For the immunoblot analysis, samples were electrophoresed, transblotted onto an Immobilon-P polyvinylidene difluoride transfer membrane (Millipore Corp., Bedford, Mass.) as described previously (18), except that the transfer buffer contained only $7.5 \%$ methanol, and blocked by exposure to $0.5 \%$ Tween 20 . The blots were developed in a solution consisting of $20 \mathrm{mg}$ of 3-amino-9-ethyl-carbazide dissolved in $5 \mathrm{ml}$ of dimethyl formamide, 95 $\mathrm{ml}$ of $0.05 \mathrm{M}$ sodium acetate $(\mathrm{pH} 5.0)$, and $100 \mu \mathrm{l}$ of $30 \%$ ( $\mathrm{vol} / \mathrm{vol})$ hydrogen peroxide.

Hybridization with the end gene probe. DNA was prepared from staphylococc that had been treated with acetone, lysozyme, and SDS as previously described (22). Hybridization analyses were performed essentially as described by Ausube et al. (6). DNA was digested with EcoRI, transferred to nitrocellulose membranes, and probed with an internal $A v a$ II fragment from the lysostaphin gene (end) that was gel purified (36) and $\left[\alpha{ }^{32} \mathrm{P}\right] \mathrm{dCTP}$ labeled with a random primed DNA labeling kit (U.S. Biochemical Corp., Cleveland, Ohio) according to the manufacturer's instructions. The results were visualized by autoradiography.

\section{RESULTS AND DISCUSSION}

Normalized ribotype patterns. Normalized ribotyping provides an approach in which a species can be viewed as an assembly of known pattern types, in contrast to conventional phenotypic typing, in which a species is divided into morphotypes and/or biotypes. When $S$. sciuri strain patterns were assembled, they could be arranged into three subdivisions or blocks on the basis of similarities (Fig. 1). The block of pattern types bounded by dd 4535 and dd 4376 in Fig. 1 represents the patterns of $S$. sciuri subsp. rodentium. These patterns are distinguished by a band at about $8.5 \mathrm{kbp}$. There is also another unique band at about $4.8 \mathrm{kbp}$ that has a high frequency of occurrence. In the two pattern types without this band, there are additional polymorphic fragments which might contain the same hybridizable region. In the block representing the strains of $S$. sciuri subsp. carnaticus, the patterns are distinguished by a dark band at $12 \mathrm{kbp}$, suggesting that there is more than one hybridizable fragment of this size. The lower intensity of this band in pattern dd 0791 could be accounted for by the band at about $6 \mathrm{kbp}$. The block of patterns at the top of Fig. 1 represents the pattern types of $S$. sciuri subsp. sciuri. The patterns of this subspecies could be distinguished either by the high intensity of a band at about $4.2 \mathrm{kbp}$ that had a high frequency of occurrence or by the presence of two separable bands at about 


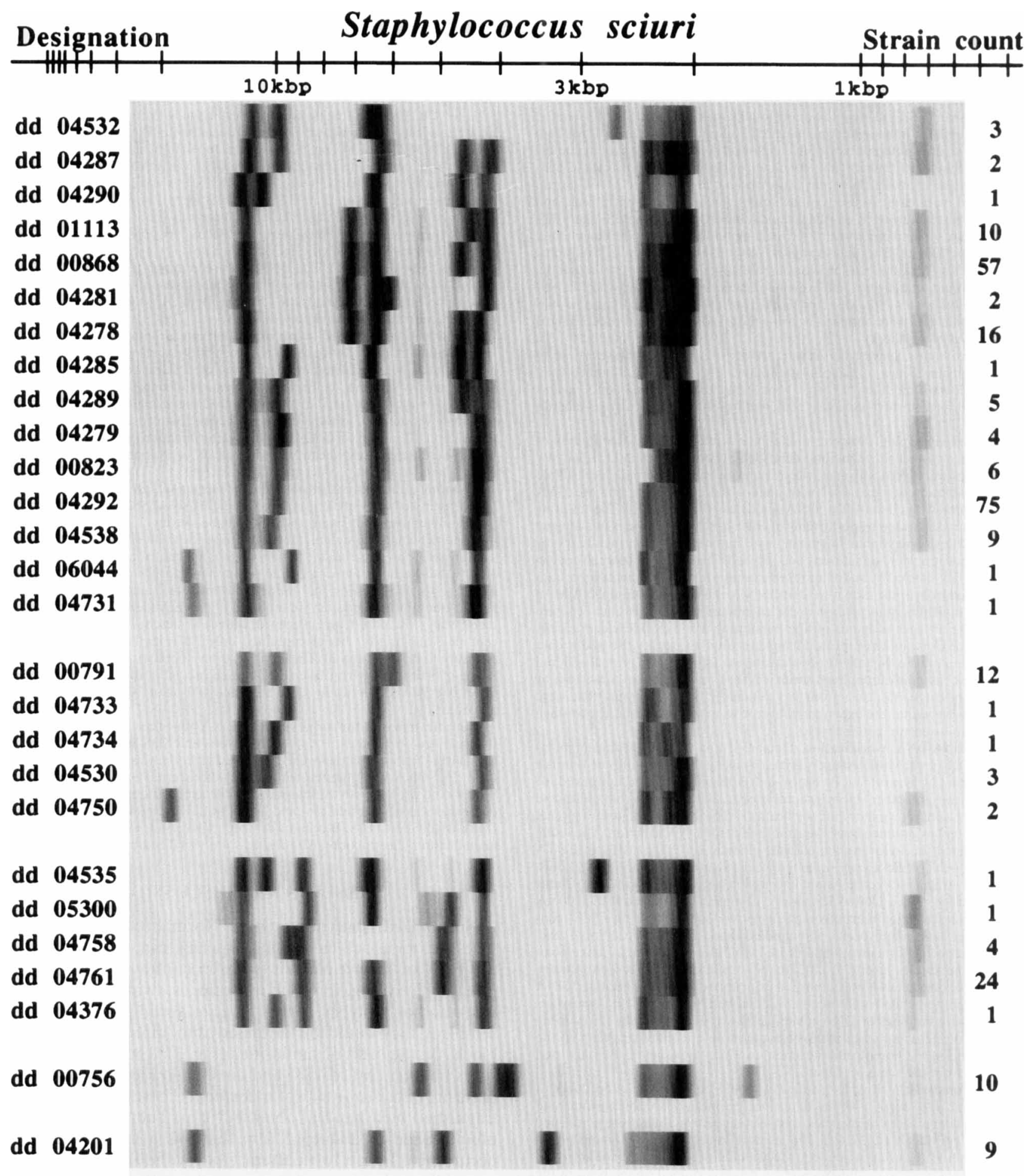

FIG. 1. Normalized ribotypes for $S$. sciuri strains and the nomenclatural type strains of the other species in the $S$. sciuri species group. The patterns delineate three subspecies of $S$. sciuri, with taxonomic resolution extending to the level of type. Patterns dd 4532 to 4731 are $S$. sciuri subsp. sciuri patterns. Patterns dd 0791 to 4750 are $S$. sciuri subsp. carnaticus patterns. Patterns dd 4535 to 4376 are $S$. sciuri subsp. rodentium patterns. Pattern dd 0756 is the pattern for the nomenclatural type strain of $S$. vitulus, and pattern dd 4201 is the pattern for the nomenclatural type strain of $S$. lentus.

4.2 and 4.3 to $4.5 \mathrm{kbp}$. When an array of patterns is accumulated for a species, similarities of pattern types can be recognized and subspecies can be defined. The separation of $S$. sciur into three subpopulations or subspecies by ribotyping correlated well with the results of other methods described below.
Pattern type dd 4201, representing the nomenclatural type strain of Staphylococcus lentus, and pattern type dd 0756, representing the nomenclatural type strain of Staphylococcus vitulus, two other species of the $S$. sciuri species group, are visually distinct from the patterns obtained for $S$. sciuri. While all data 
TABLE 2. Results of hybridization of staphylococcal DNAs with [methyl- $\left.{ }^{3} \mathrm{H}\right]$ thymidine-labeled DNAs from the $S$. sciuri subspecies

\begin{tabular}{|c|c|c|c|c|c|c|c|c|}
\hline \multirow{4}{*}{ Species or subspecies } & \multirow{4}{*}{$\begin{array}{l}\text { Ribotype } \\
\text { pattern } \\
\text { type }\end{array}$} & \multirow{4}{*}{ Strain } & \multicolumn{6}{|c|}{ \% Relative binding with labeled DNA from: } \\
\hline & & & \multicolumn{3}{|c|}{$\begin{array}{l}\text { S. sciuri } \text { subsp. sciuri } \\
\text { strains }\end{array}$} & \multicolumn{2}{|c|}{$\begin{array}{l}\text { S. sciuri subsp. } \\
\text { carnaticus } \text { strains }\end{array}$} & \multirow{3}{*}{$\begin{array}{l}\text { S. sciuri subsp. rodentium } \\
\text { DD } 4761^{\mathrm{T}}\left(70^{\circ} \mathrm{C}\right)\end{array}$} \\
\hline & & & \multicolumn{2}{|c|}{ DD $4277^{T}$} & \multirow{2}{*}{$\begin{array}{c}\text { DD } 4537 \\
\left(70^{\circ} \mathrm{C}\right)\end{array}$} & \multirow{2}{*}{$\begin{array}{c}\text { DD } 791^{\mathrm{T}} \\
\left(70^{\circ} \mathrm{C}\right)\end{array}$} & \multirow{2}{*}{$\begin{array}{c}\text { DD } 6081 \\
\left(70^{\circ} \mathrm{C}\right)\end{array}$} & \\
\hline & & & $55^{\circ} \mathrm{C}$ & $70^{\circ} \mathrm{C}$ & & & & \\
\hline \multirow[t]{10}{*}{ S. sciuri subsp. sciuri } & dd 0868 & DD $4277^{\mathrm{T}}$ & $100^{a}$ & 100 & 80 & 64 & 63 & 58 \\
\hline & dd 0868 & DD 4274 & & 92 & 81 & 60 & 59 & 65 \\
\hline & dd 4281 & DD 4281 & & 98 & 81 & & & \\
\hline & dd 4289 & DD 4289 & & 100 & 80 & 60 & 59 & 57 \\
\hline & dd 4532 & DD 5748 & 84 & $\mathbf{8 8}$ & 79 & 64 & 61 & 60 \\
\hline & dd 4292 & DD 4537 & 91 & 83 & 100 & 62 & 51 & 63 \\
\hline & dd 4292 & DD 5256 & & 80 & $\mathbf{8 2}$ & 67 & 61 & 57 \\
\hline & dd 0823 & DD 6059 & & 84 & 90 & & & \\
\hline & dd 4731 & DD 4731 & & 83 & 98 & 66 & 58 & 56 \\
\hline & dd 6044 & DD 6044 & & 85 & 90 & 62 & 65 & 55 \\
\hline \multirow[t]{7}{*}{ S. sciuri subsp. carnaticus } & dd 0791 & DD $791^{\mathrm{T}}$ & 68 & 68 & 66 & 100 & 90 & 63 \\
\hline & dd 0791 & DD 5284 & & 67 & 65 & 85 & 81 & 68 \\
\hline & dd 0791 & DD 5254 & 73 & 70 & 61 & 81 & 98 & 65 \\
\hline & dd 4750 & DD 6081 & 72 & 60 & 69 & 89 & 100 & 67 \\
\hline & dd 4750 & DD 4750 & & 73 & 64 & 98 & 86 & 61 \\
\hline & dd 4530 & DD 4530 & & 72 & & 81 & & 64 \\
\hline & dd 4530 & DD 5666 & & 61 & & 99 & & 61 \\
\hline \multirow[t]{4}{*}{ S. sciuri subsp. rodentium } & dd 4761 & DD $4761^{T}$ & 67 & 64 & 68 & 65 & 54 & 100 \\
\hline & dd 4761 & DD 5282 & & & & & & 80 \\
\hline & dd 4535 & DD 4535 & 74 & 51 & 63 & 65 & 53 & 88 \\
\hline & dd 4758 & DD 6077 & 74 & 49 & 58 & 54 & 62 & 86 \\
\hline S. vitulus & dd 0756 & DD $756^{\mathrm{T}}$ & & 18 & 15 & 14 & 14 & 14 \\
\hline S. lentus & dd 4201 & DD $4203^{\mathrm{T}}$ & & 15 & 13 & 10 & 10 & 14 \\
\hline
\end{tabular}

${ }^{a}$ The values in boldface type are intrasubspecies values.

are not shown, sets of fragments that are conserved in different strains of a particular species are not conserved as a set in the strains of any other of the more than 200 species studied to date $(11,12,23,59)$.

DNA-DNA hybridization studies. The DNA relationships among selected $S$. sciuri strains representing the major ribotype pattern types, several minor types, and other species of the $S$. sciuri species group are shown in Table 2. The data show that each proposed subspecies forms a separate, well-defined DNA similarity group at the stringent criterion $\left(70^{\circ} \mathrm{C}\right)$. Strains of the same subspecies exhibited high levels of DNA relatedness (mean relative level of binding in reassociation reactions, $87 \%$; range, 79 to $100 \%$ ), whereas, strains of different subspecies exhibited significantly lower levels of DNA relatedness (mean relative level of binding, 62\%; range, 49 to $73 \%$ ). The levels of DNA relatedness of three representative strains of each subspecies to $S$. sciuri subsp. sciuri determined under the optimal conditions $\left(55^{\circ} \mathrm{C}\right)$ (mean relative level of binding, $71 \%$; range, 67 to $74 \%$ ) support the conclusion that these similarity groups should be given subspecies status rather than species status. Nevertheless, the extents of DNA divergence between subspecies appear to be quite large and suggest that the subspecies are approaching species status.

Phenotypic characterization. Cells were gram-positive cocci (diameter, 0.7 to $1.2 \mu \mathrm{m}$ ), that were nonmotile, did not form spores, and were arranged singly, in pairs, and in tetrads. $S$. sciuri is a facultative anaerobe, although growth is much better under aerobic conditions. All strains were positive for catalase, oxidase (as determined by the Microdase disk test), and $\beta$-glu- cosidase activities and esculin hydrolysis and produced acid aerobically from D-glucose, glycerol, $\beta$-D-fructose, sucrose, and D-ribose. All strains except strain DD 4537 reduced nitrate to nitrite. All strains were negative for staphylocoagulase, thermonuclease, pyrrolidonyl arylamidase, ornithine decarboxylase, urease, $\beta$-glucuronidase, and $\beta$-galactosidase activities and arginine utilization and failed to produce acid aerobically from raffinose, xylitol, and melibiose and anaerobically from D-mannitol. All strains except strain DD 5748 failed to produce acid aerobically from $N$-acetylglucosamine. All strains were borderline negative or weakly positive in the STAPH Trac VogesProskauer test for acetoin. However, in the ID32 STAPH Voges-Proskauer test and standard methyl red-Voges Proskauer medium, all strains except DD 4289 were negative; strain DD 4289 was weakly positive. Characteristics that were variable for S. sciuri are listed in Table 3. Several of the phenotypic characteristics were expressed differently in the different subspecies and, therefore, had some discriminatory value. For example, a high percentage of the strains of $S$. sciuri subsp. rodentium gave moderate to strong positive reactions in the latex agglutination test for clumping factor and protein $\mathrm{A}$, whereas the strains of $S$. sciuri subsp. sciuri were negative in this test. All strains of $S$. sciuri subsp. carnaticus produced acid from D-xylose but failed to produce acid from D-melezitose, and all strains of $S$. sciuri subsp. sciuri produced acid from D-cellobiose.

Antibiotic resistance. Breakpoints established for $S$. aureus were used for classifying $S$. sciuri strains as "susceptible", "intermediate resistant", or "resistant" to all of the antibiotics tested except novobiocin. All strains of $S$. sciuri were resistant 
TABLE 3. Variable characteristics of S. sciuri subspecies

\begin{tabular}{|c|c|c|c|}
\hline \multirow[b]{2}{*}{ Characteristic } & \multicolumn{3}{|c|}{$\begin{array}{c}\% \text { of strains positive } \\
\text { (\% of strains weakly positive) }\end{array}$} \\
\hline & $\begin{array}{l}S . \text { sciuri } \\
\text { subsp. } \\
\text { sciuri } \\
(n=26)\end{array}$ & $\begin{array}{c}S . \text { sciuri } \\
\text { subsp. } \\
\text { carnaticus } \\
(n=14)\end{array}$ & $\begin{array}{l}S . \text { sciuri } \\
\text { subsp. } \\
\text { rodentium } \\
(n=18)\end{array}$ \\
\hline P-agar colony diam $\geq 7 \mathrm{~mm}$ & 65 & 7 & 33 \\
\hline $\begin{array}{l}\text { Pigment (cream-yellow, yellow, } \\
\text { or orange-gray) }\end{array}$ & 69 & 57 & 44 \\
\hline Anaerobic growth & $23(62)$ & $0(64)$ & $0(44)$ \\
\hline Hemolysis (bovine blood) & $8(92)$ & $0(100)$ & $0(100)$ \\
\hline Staph Latex agglutination & 0 & 36 & 94 \\
\hline Staph-A-Lex agglutination & 0 & 0 & $89(6)$ \\
\hline Alkaline phosphatase activity & $85(8)$ & 29 & 67 \\
\hline Staphylolytic activity & $88(12)$ & $71(14)$ & $77(11)$ \\
\hline Oxacillin resistance $^{a}$ & $27(38)$ & $7(29)$ & $56(33)$ \\
\hline Methicillin resistance ${ }^{b}$ & $4(38)$ & $0(14)$ & $22(44)$ \\
\hline Cefazolin resistance $^{c}$ & 0 & 0 & $0(28)$ \\
\hline \multicolumn{4}{|l|}{ Acid produced aerobically from: } \\
\hline D-Xylose & 12 & $93(7)$ & 17 \\
\hline D-Melezitose & $54(8)$ & 0 & 44 \\
\hline D-Cellobiose & $88(12)$ & $29(29)$ & $56(11)$ \\
\hline D-Sorbitol & 77 & $71(7)$ & $28(6)$ \\
\hline L-Arabinose & $38(15)$ & $14(7)$ & $22(33)$ \\
\hline D-Mannose & $65(19)$ & $64(21)$ & $83(17)$ \\
\hline$\alpha$-Lactose & 15 & 29 & 0 \\
\hline D-Fucose & $92(4)$ & 100 & 67 \\
\hline D-Trehalose & $81(12)$ & $93(7)$ & $56(44)$ \\
\hline Maltose & $15(35)$ & $50(50)$ & $17(72)$ \\
\hline D-Mannitol & $96(4)$ & 93 & 100 \\
\hline Salicin & $69(8)$ & 86 & 89 \\
\hline$\alpha$-L-Rhamnose & 12 & 0 & 6 \\
\hline
\end{tabular}

${ }^{a}$ Diameters of zones of inhibition for $1-\mu \mathrm{g}$ discs were interpreted as follows: 6 to $10 \mathrm{~mm}$, resistant (positive); 11 to $12 \mathrm{~mm}$, intermediate resistance (weakly positive).

${ }^{b}$ Diameters of zones of inhibition for $5-\mu \mathrm{g}$ discs were interpreted as follows: 6 to $9 \mathrm{~mm}$, resistant (positive); 10 to $13 \mathrm{~mm}$, intermediate resistance (weakly positive).

${ }^{c}$ Diameters of zones of inhibition for $30-\mu \mathrm{g}$ discs were interpreted as follows: 6 to $14 \mathrm{~mm}$, resistant (positive); 15 to $17 \mathrm{~mm}$, intermediate resistance (weakly positive).

to novobiocin on the basis of breakpoints established for Staphylococcus saprophyticus (29). All strains were also resistant to penicillin $\mathrm{G}$, although there was significant variation (10-U disk inhibition zone diameters, 10 to $28 \mathrm{~mm}$ ) in the level of resistance. Most strains were susceptible to tetracycline, erythromycin, and clindamycin. Strains DD 5262, DD 4780, DD 4750 , and DD 5238 were resistant to tetracycline. Strain DD $791^{\mathrm{T}}$ ( $\mathrm{T}=$ type strain) was resistant to erythromycin. Strains DD 4776 and DD 792 were multiply resistant to tetracycline, erythromycin, and clindamycin. All strains were susceptible to vancomycin. Most strains were susceptible to gentamicin and sulfamethoxazole-trimethoprim. Strains DD 4371, DD 6272, DD 6273, DD 6278, DD 6281, and DD 6282 were resistant to gentamicin. Strains DD 792 and DD 6276 were resistant to sulfamethoxazole-trimethoprim. Strains exhibited either intermediate resistance ( $83 \%$ of the strains) or nearintermediate resistance (17\% of the strains) to ciprofloxacin, and this property may be related to the intrinsic resistance of the organisms to novobiocin and nalidixic acid, other antibiotics that inhibit DNA gyrase activity.

Many strains of $S$. sciuri were either resistant or showed intermediate resistance to oxacillin and methicillin, and some strains showed intermediate resistance to cefazolin. The frequencies and levels of resistance to these antibiotics were gen- erally higher in $S$. sciuri subsp. rodentium than in the other subspecies (Table 3 ). The diameters of the halos for oxacillin (1- $\mu \mathrm{g}$ disc), methicillin $(5-\mu \mathrm{g}$ disc), cefazolin $(30-\mu \mathrm{g}$ disc), and cephalothin (30- $\mu \mathrm{g}$ disc) for the subspecies were as follows: $S$. sciuri subsp. sciuri, $12 \pm 4,14 \pm 3,26 \pm 3$, and $29 \pm 3 \mathrm{~mm}$, respectively; and $S$. sciuri subsp. carnaticus, $14 \pm 3,15 \pm 3$, $27 \pm 3$, and $29 \pm 3 \mathrm{~mm}$, respectively; and $S$. sciuri subsp. rodentium, $10 \pm 4,12 \pm 5,21 \pm 5$, and $24 \pm 4 \mathrm{~mm}$, respectively. For many strains, colonies were observed in the halos produced by the oxacillin and methicillin discs. S. sciuri subsp. rodentium DD 4535, DD 6272, DD 6273, and DD 6282, which exhibited the highest levels of oxacillin and methicillin resistance, produced growth up to the edges of the discs. In the case of $S$. aureus, the inhibition zones included a wide range of MICs, from MICs characteristic of susceptible and/or borderline resistant strains to MICs of highly oxacillin-resistant strains. The mechanisms of oxacillin (and methicillin) resistance in these strains is not yet clear. Chromosomal DNAs prepared from all $40 \mathrm{~S}$. sciuri strains tested (20 S. sciuri subsp. sciuri strains, $6 \mathrm{~S}$. sciuri subsp. carnaticus strains, and $14 S$. sciuri subsp. rodentium strains) gave positive signals with a $m e c A$-specific DNA probe, suggesting that a gene closely related to the $m e c A$ gene of methicillin-resistant strains of $S$. aureus and certain other staphylococcal species was present $(5$, 47,56 ). The results of dot blot hybridization of 20 selected strains are shown in Fig. 2. The fact that all of the strains of $S$. sciuri tested hybridized with the mec $A$ gene probe raises the possibility that $S$. sciuri may be an important reservoir of genetic determinants of methicillin resistance. Several other investigators have observed hybridization of a mecA-specific DNA probe with the chromosomal DNAs of a few isolates of $S$. sciuri $(39,48,54)$. A preliminary report (13) indicated that a homolog of the regulatory gene $m e c I / m e c R$ was also detected recently in a group of $S$. sciuri subsp. rodentium strains taken from the present investigation. One attractive hypothesis to consider is that a homolog of the $m e c A$ gene is intrinsic to $S$. sciuri and encodes one of the penicillin-binding proteins of this species $(25,42)$. A study of the genetic interactions of $S$. sciuri with other members of the microbial community would be an

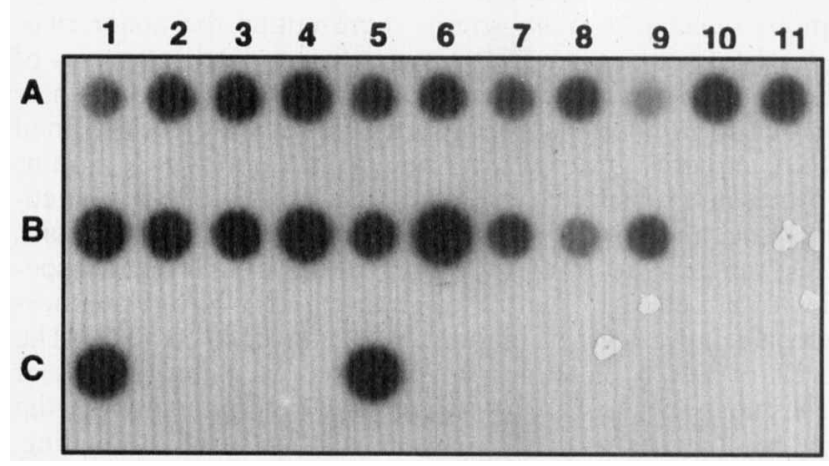

FIG. 2. Dot blot hybridization of $S$. sciuri lysates with the $S$. aureus mecA probe. The approximate amounts of DNAs loaded on the membrane are indicated in parentheses below. Samples A1 to A11 were lysates of $S$. sciuri subsp. sciuri DD $4281(32 \mu \mathrm{g})$, DD $4278(37 \mu \mathrm{g})$, DD $4295(43 \mu \mathrm{g})$, DD $4292(39 \mu \mathrm{g})$, DD $4276(36 \mu \mathrm{g})$, DD $4274(37 \mu \mathrm{g})$, DD $4285(41 \mu \mathrm{g})$, DD $4289(45 \mu \mathrm{g})$, DD $4279(10 \mu \mathrm{g})$, DD $4277^{\mathrm{T}}(34 \mu \mathrm{g})$, and DD $4537(39 \mu \mathrm{g})$, respectively; samples B1 to B8 were lysates of $S$. sciuri subsp. rodentium DD $6272(16 \mu \mathrm{g})$, DD 6273 (38 $\mu \mathrm{g}), \mathrm{DD} 6278(37 \mu \mathrm{g})$, DD $6281(43 \mu \mathrm{g}), \mathrm{DD} 6282(43 \mu \mathrm{g}), \mathrm{DD} 4535(39 \mu \mathrm{g})$, DD $4761^{\mathrm{T}}(42 \mu \mathrm{g})$, and DD $5282(39 \mu \mathrm{g})$, respectively; and sample B9 was a lysate of $S$. sciuri subsp. carnaticus DD $792(37 \mu \mathrm{g})$. Reference sample $\mathrm{Cl}$ was a lysate of methicillin-resistant $S$. aureus COL $(30 \mu \mathrm{g})$; sample C3 was a lysate of methicillin-susceptible $S$. aureus RN $2677(30 \mu \mathrm{g})$; and sample C5 was a lysate of $S$ aureus $\mathrm{N} 315(30 \mu \mathrm{g})$. 


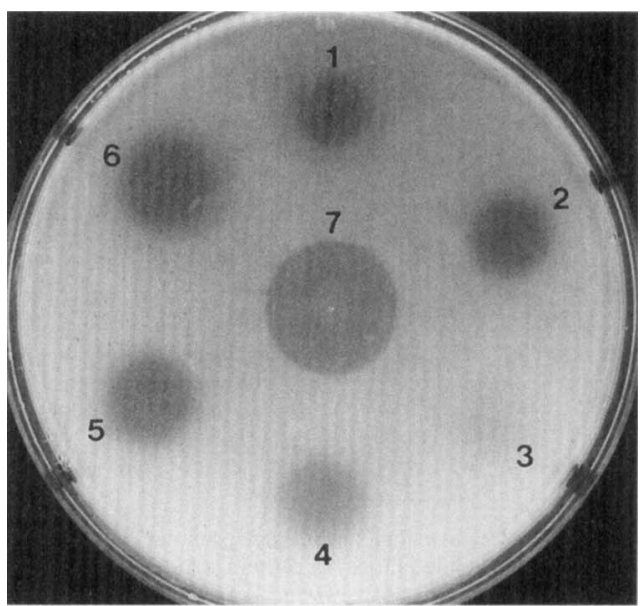

FIG. 3. Production of extracellular staphylolytic enzyme activity by colonies grown on an indicator plate containing heat-killed cells of $S$. aureus ATCC 6538P After growth for $24 \mathrm{~h}$, the colonies were washed from the plate to allow easier visualization of the zones of bacteriolysis. Spot $1, S$. sciuri subsp. sciuri DD $4277^{\mathrm{T}}$ spot 2, S. sciuri subsp. carnaticus DD 5255; spot 3, S. sciuri subsp. sciuri DD 4520; spot 4, S. sciuri subsp. sciuri DD 5262; spot 5, S. sciuri subsp. rodentium DD 6282, spot $6, S$. sciuri subsp. sciuri DD 4747 ; spot 7, S. simulans biovar staphylolyticus NRRL B-2628.

important step toward understanding the mechanisms of gene flow from this primitive, commensal species to the more specialized, pathogenic species of medical interest.

Staphylolytic enzymes. All strains of $S$. sciuri subsp. sciuri, 11 of $14 S$. sciuri subsp. carnaticus strains (79\%), and 16 of $18 S$. sciuri subsp. rodentium strains $(89 \%)$ exhibited extracellular staphylolytic activity when a lysis plate test was used. The staphylolytic activities of several representative strains are shown in Fig. 3. Staphylolytic activity was detected in all six $S$. lentus strains and 4 of the $11 S$. vitulus strains tested, but it was observed infrequently in the other staphylococcal species indigenous to lower mammals. This activity is at least in part due to the production of a staphylolytic enzyme that is immunologically related to lysostaphin (Table 4), an endopeptidase that has as its main target the polyglycyl bridge of the cell wall peptidoglycan of staphylococci (55). The staphylolytic activity profiles and an immunoblot with lysostaphin-specific MAb of selected strains are shown in Fig. 4. Even though most strains reacted with the lysostaphin-specific MAb, only three reactive strains (DD 4747, DD 5262, and DD 6282) hybridized with the end gene probe (Table 4). These results suggest that the staphylolytic activity of most strains is due to the presence of an enzyme other than lysostaphin that shares an immunological domain or epitope and is determined by a different gene exhibiting little nucleotide sequence homology with end. A survey of the total DNAs of many other staphylococcal species indigenous to lower mammals, including $S$. vitulus and $S$. lentus of the $S$. sciuri species group, Staphylococcus caseolyticus, Staphylococcus hyicus, Staphylococcus chromogenes, Staphylococcus delphini, Staphylococcus intermedius, Staphylococcus schleiferi, Staphylococcus felis, Staphylococcus simulans, Staphylococcus carnosum, Staphylococcus gallinarum, Staphylococcus equorum, Staphylococcus kloosii, and Staphylococcus xylosus, failed to detect any hybridization with the end gene probe. Lysostaphin susceptibility was generally inversely related to staphylolytic enzyme production (Table 4).

Cell wall composition. Cell wall peptidoglycan and teichoic acid compositions were determined for several selected strains, including S. sciuri subsp. sciuri DD 4274, DD 4276, DD $4277^{\mathrm{T}}$,
DD 4278, and DD 4285 (determined previously [33]), S. sciuri subsp. sciuri DD 4520 and DD $4526, S$. sciuri subsp. carnaticus DD $791^{\mathrm{T}}$, and $S$. sciuri subsp. rodentium DD $4761^{\mathrm{T}}$. The peptidoglycan type of each of the $S$. sciuri subspecies is L-Lys-LAla-Gly $_{3-4}$. This peptidoglycan type is also found in $S$. lentus and $S$. vitulus. Low levels of $\mathrm{L}$-serine $(0.1$ to $0.4 \mathrm{~mol} / \mathrm{mol}$ of glutamic acid) were detected in the peptidoglycans of strains DD 4278, DD 4285, DD 4287, and DD $4761^{\mathrm{T}}$. The main cell wall teichoic acid type of many $S$. sciuri strains is poly(glycerolphosphate- $N$-acetylglucosaminylphosphate) (19). However, strain DD 4520 has this type only partially (30 to $40 \%$ ); the remaining types have not been investigated in detail. Strains DD $791^{\mathrm{T}}$ and DD 4526 have a polyglycerolphosphate type with $\mathrm{N}$-acetylglucosamine substitution. Strain DD 4278 has a teichoic acid containing ribitol instead of glycerol (33); strains SC

TABLE 4. Lysostaphin susceptibility, staphylolytic enzyme production, and reactivity with lysostaphin-specific MAb and lysostaphin gene probe for selected strains

\begin{tabular}{|c|c|c|c|c|}
\hline Organism & $\begin{array}{l}\text { Lysostaphin } \\
\text { suscepti- } \\
\text { bility }^{a}\end{array}$ & $\begin{array}{l}\text { Staphylolytic } \\
\text { enzyme } \\
\text { production } \\
\text { (U/mg [dry } \\
\text { cell wt]) }\end{array}$ & $\begin{array}{c}\text { Reactivity } \\
\text { with } \\
\mathbf{M A b}^{b}\end{array}$ & $\begin{array}{c}\text { Reactivity } \\
\text { with gene } \\
\text { probe }^{c}\end{array}$ \\
\hline \multicolumn{5}{|c|}{$\begin{array}{c}\text { S. simulans biovar staph- } \\
\text { ylolyticus strains }\end{array}$} \\
\hline Wild type & 1.0 & 2.27 & + & + \\
\hline JN351 & 26.0 & $<0.02$ & - & - \\
\hline S. aureus FDA 209P & 23.4 & $<0.02$ & - & - \\
\hline \multicolumn{5}{|l|}{$\begin{array}{l}\text { S. sciuri subsp. sciuri } \\
\text { strains }\end{array}$} \\
\hline DD $4277^{\mathrm{T}}$ & 10.8 & 0.23 & + & - \\
\hline DD 4287 & 6.2 & 0.36 & + & - \\
\hline DD 4520 & 19.8 & $<0.02$ & - & - \\
\hline DD 5277 & 2.6 & 0.34 & + & - \\
\hline DD 5272 & 7.2 & 0.34 & + & - \\
\hline D'D 4747 & 5.6 & 0.43 & + & + \\
\hline DD 5262 & 3.4 & 0.11 & + & + \\
\hline \multicolumn{5}{|l|}{$\begin{array}{l}\text { S. sciuri subsp. carnati- } \\
\text { cus } \text { strains }\end{array}$} \\
\hline DD $791^{\mathrm{T}}$ & 3.4 & 0.06 & - & - \\
\hline DD 5254 & 8.8 & 0.35 & + & - \\
\hline DD 5268 & 4.4 & 0.36 & + & - \\
\hline DD 5255 & 2.0 & 0.35 & + & - \\
\hline DD 5238 & 3.2 & 0.34 & + & - \\
\hline \multicolumn{5}{|l|}{$\begin{array}{l}\text { S. sciuri subsp. roden- } \\
\text { tium strains }\end{array}$} \\
\hline DD $4761^{\mathrm{T}}$ & 3.4 & 0.37 & + & - \\
\hline DD 4762 & 3.0 & 0.31 & + & - \\
\hline DD 4776 & 4.6 & 0.32 & + & - \\
\hline DD 4778 & 5.2 & 0.34 & + & - \\
\hline DD 5283 & 4.0 & 0.33 & + & - \\
\hline DD 6077 & 5.8 & 0.32 & + & - \\
\hline DD 6272 & 4.8 & 0.36 & + & - \\
\hline DD 6273 & 4.2 & 0.36 & + & - \\
\hline DD 6276 & 4.2 & 0.35 & + & - \\
\hline DD 6278 & 2.6 & 0.34 & + & - \\
\hline DD 6282 & 2.2 & 0.16 & + & + \\
\hline
\end{tabular}

${ }^{a}$ Rate of lysis (change in optical density at $620 \mathrm{~nm}$ in $10 \mathrm{~min}$ ) of heat-treated cells divided by the rate of lysis of heat-treated cells of wild-type $S$. simulans biovar staphylolyticus NRRL B-2628 when standardized suspensions were exposed to $1 \mathrm{U}$ of lysostaphin per $\mathrm{ml}$.

${ }^{b}$ As determined by an enzyme-linked immunosorbent assay and immunoblotting.

As determined by a Southern hybridization analysis. 


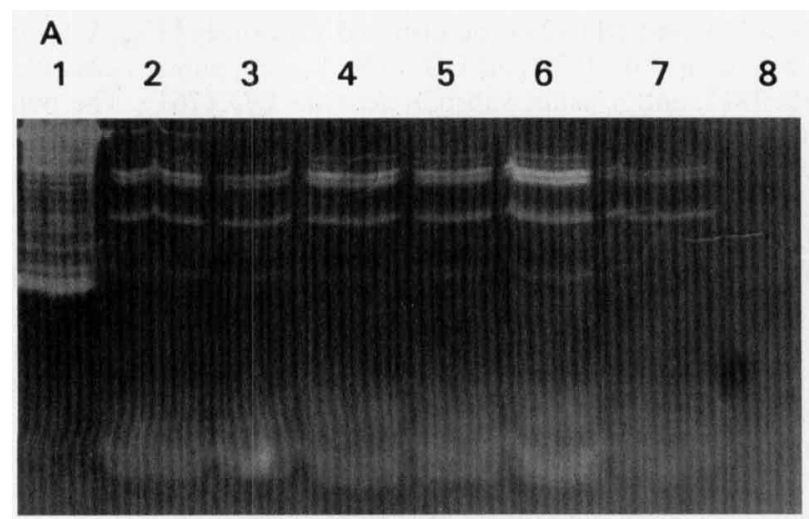

B

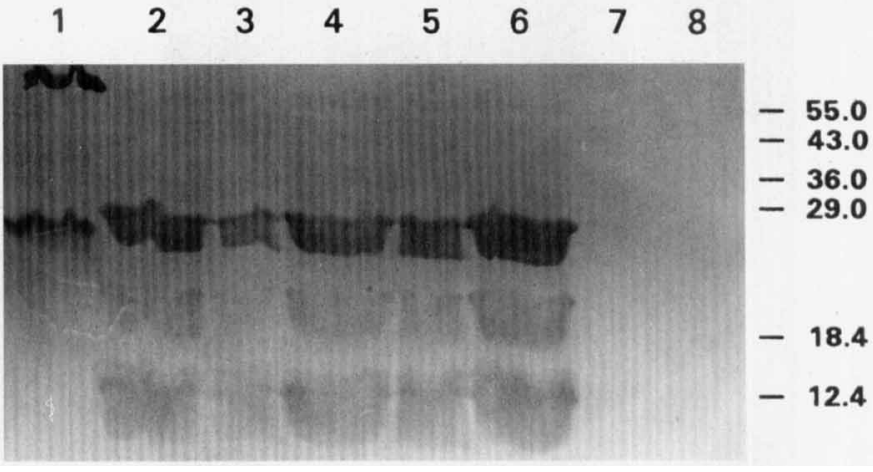

FIG. 4. Staphylolytic activity profiles (A) and immunoblot results (B) obtained with lysostaphin-specific MAb for concentrated samples from stationary-phase culture supernatant fluids after SDS-polyacrylamide gel electrophoresis. The positions and molecular masses (in kilodaltons) of protein standards are indicated on the right. Lane 1, S. simulans biovar staphylolyticus NRRL B-2628; lane 2, S. sciuri subsp. sciuri DD 4287; lane 3, S. sciuri subsp. carnaticus DD 5254; lane 4, S. sciuri subsp. rodentium DD 6077 ; lane 5, S. sciuri subsp. carnaticus DD 5268; lane 6, S. sciuri subsp. rodentium DD $4761^{\mathrm{T}} ;$ lane $7, S$. sciuri subsp. rodentium DD 6282 ; lane $8, S$. sciuri subsp. sciuri DD 4520.

225 (33) and DD $4761^{\mathrm{T}}$ have a polyglycerolphosphate type that is substituted with glucose instead of $N$-acetylglucosamine.

DNA base composition. The $\mathrm{G}+\mathrm{C}$ contents of the DNAs of selected strains, including $S$. sciuri subsp. sciuri DD 4274, DD 4276, DD $4277^{\mathrm{T}}$, and DD 4278 (33), S. sciuri subsp. carnaticus DD $791^{\mathrm{T}}$, and $S$. sciuri subsp. rodentium DD $4761^{\mathrm{T}}$ were in a narrow range, 35 to $36 \mathrm{~mol} \%$.

Description of Staphylococcus sciuri subsp. sciuri Kloos, Schleifer, and Smith 1976, $2^{\mathrm{AL}}$ emend. Kloos et al. 1996. The description below is based on the characteristics of 35 strains isolated in 1971 through 1975 and reported on previously (33) and an additional 15 strains isolated in 1992 for this study. Of these 50 strains, 26 (11 of the previously described strains and the 15 new strains) were selected to examine additional phenotypic characteristics not reported on previously, including pyrrolidonyl arylamidase, thermonuclease, ornithine decarboxylase, and staphylolytic enzyme activities, clumping factor and protein A (as determined by latex agglutination), esculin hydrolysis, and oxacillin and methicillin resistance. Colonies grow to $7 \pm 2 \mathrm{~mm}$ in diameter on $\mathrm{P}$ agar and to $10 \pm 2 \mathrm{~mm}$ in diameter on TSA. A more complete description of colony morphology and pigmentation on $\mathrm{P}$ agar is given in the original description of the subspecies (33). Glucose fermentation is weak, and the terminal $\mathrm{pH}$ is 5.7 to 6.0 . Growth in the anaerobic portion of semisolid thioglycolate medium ranges from no detectable growth to moderate growth, depending on the strain. Low levels of L-lactic acid are produced from glucose (33). Menaquinones are unsaturated and are composed mainly of six isoprenoid units (MK-6) (40). Catalase is produced, and this enzyme is immunologically distinct and not closely related to the catalases of other species (51). Growth is good at $\mathrm{NaCl}$ concentrations up to $10 \%$. The optimum growth temperatures are $35^{\circ} \mathrm{C}$ on $\mathrm{P}$ agar and 35 to $40^{\circ} \mathrm{C}$ on TSA. Growth is absent or very poor at $45^{\circ} \mathrm{C}$. Strains exhibit moderate to strong caseinolytic and gelatinase activities, but do not exhibit lipolytic and elastase activities (33). Staphylolytic enzyme activity is weak to moderate. Clumping factor and protein A are not produced. All strains produce acid aerobically from D-cellobiose and D-mannitol. Other characteristics of $S$. sciuri subsp. sciuri that are uniformly positive or negative for the species are listed above. The variable characteristics for this subspecies are listed in Table 3. The major API STAPH-IDENT profile is $5710(92 \%)$; the major STAPH Trac profile is $6736150(69 \%)$. The major ribotype pattern types are dd $4292(39 \%)$ and dd
$0868(30 \%)$. Fifteen different ribotype patterns have been described (Fig. 1). The $\mathrm{G}+\mathrm{C}$ content of the DNA is 35 to 36 mol\%. This subspecies is widely distributed in nature and may have various mammalian and transient bird hosts, although it is seldom found on humans and apes (27, 28, 31-33).

Amended description of type strain ATCC 29062 (Kloos, Schleifer, and Smith 1976). Strain ATCC 29062 (= SC $116=$ DD 4277), which was isolated from the skin of an eastern gray squirrel, is the type strain of S. sciuri subsp. sciuri (33). It has all of the uniform characteristics of the subspecies described previously and above and, in addition, has the properties listed below.

Spherical cells (diameter, 0.8 to $1.2 \mu \mathrm{m}$ ) that occur singly, in pairs, and in tetrads.

Circular P-agar colonies are 9 to $10 \mathrm{~mm}$ in diameter, have moderately undulate edges, are raised with slightly elevated centers, are smooth with glistening surfaces, and are translucent to opaque with a yellow-gray pigment. Colonies on TSA are 10 to $11 \mathrm{~mm}$ in diameter.

Facultatively anaerobic. Delayed weak growth occurs in the anaerobic portion of thioglycolate medium.

No hemolysis of bovine, sheep, or horse blood occurs.

Moderate alkaline phosphatase and staphylolytic enzyme activities.

Moderate amounts of acid are produced aerobically from D-melezitose, D-cellobiose, L-arabinose, D-fucose, D-trehalose, salicin, D-sorbitol, and D-mannitol. Weak acid is produced aerobically from maltose and D-mannose. No acid is produced from D-xylose, $\alpha$-lactose, and $\alpha$-L-rhamnose.

Intermediate resistance to oxacillin.

Type dd 0868 ribotype pattern.

The cell wall peptidoglycan is L-Lys-L-Ala-Gly ${ }_{4}$; the teichoic acid is poly(glycerolphosphate- $N$-acetylglucosaminylphosphate).

The $\mathrm{G}+\mathrm{C}$ content of the DNA is $36.5 \mathrm{~mol} \%$.

Description of Staphylococcus sciuri subsp. carnaticus subsp. nov. Staphylococcus sciuri subsp. carnaticus (car.na'ti.cus. Med. L. adj. carnaticus, pertaining to meat). The description below is based on the characteristics of 14 strains isolated in 1991 and 1992. Colonies grow to $5 \pm 2 \mathrm{~mm}$ in diameter on $P$ agar and to $9 \pm 1 \mathrm{~mm}$ in diameter on TSA. Many strains $(50 \%$ of the strains) produce small (diameter, 3 to $4 \mathrm{~mm}$ ) colonies on $P$ agar. Growth in the anaerobic portion of semisolid thioglycolate medium ranges from no detectable growth to weak, de- 
layed growth. The optimum growth temperatures are $35^{\circ} \mathrm{C}$ on $\mathrm{P}$ agar and 35 to $40^{\circ} \mathrm{C}$ on TSA. Growth is absent or very poor at $45^{\circ} \mathrm{C}$. Culture growth produces hemolysis (greening) of bovine and horse blood. All strains produce acid aerobically from D-xylose, D-fucose, D-trehalose, and maltose. Acid production from maltose is weak to moderate. Acid is not produced from D-melezitose and $\alpha$-L-rhamnose. Other characteristics of $S$. sciuri subsp. carnaticus that are uniformly positive or negative for the species are listed above. The variable characteristics for this subspecies are listed in Table 3. The major API STAPHIDENT profiles are $4710(50 \%), 4000(21 \%)$, and $5710(21 \%)$; the major STAPH Trac profiles are $6736550(36 \%)$ and $6336550(29 \%)$. The major ribotype pattern type is dd 0791 $(63 \%)$. Five different ribotype patterns have been described (Fig. 1). The $\mathrm{G}+\mathrm{C}$ content of the DNA is $36 \mathrm{~mol} \%$. This subspecies is found mainly living on bovine (artiodactyl) hosts and their meat products.

Description of the type strain. The type strain of $S$. sciuri subsp. carnaticus DD 791 (= ATCC 700058), which was isolated from a sliced veal leg. It has all of the uniform characteristics of the subspecies described above and, in addition, has the properties listed below.

Spherical cells (diameter, 0.7 to $1.2 \mu \mathrm{m}$ ) occur singly, in pairs, and in tetrads.

Circular P-agar colonies are 5 to $6 \mathrm{~mm}$ in diameter, have moderately undulate edges, have raised edges with depressed centers, are smooth with glistening surfaces, are translucent to opaque, and have sectors that are unpigmented to slightly cream tinted. Colonies on TSA are 8 to $9 \mathrm{~mm}$ in diameter.

Facultatively anaerobic. Delayed weak growth occurs in the anaerobic portion of thioglycolate medium.

Partial hemolysis (greening) of bovine and horse blood occurs. No hemolysis of sheep blood occurs.

Moderate alkaline phosphatase activity and weak staphylolytic enzyme activity.

Clumping factor and protein $\mathrm{A}$ are not detected by latex agglutination.

Moderate amounts of acid are produced aerobically from D-xylose, D-sorbitol, D-mannose, $\alpha$-lactose, salicin, D-mannitol, $D$-tehalose, and maltose. No acid is produced from D-cellobiose and L-arabinose.

Resistant to erythromycin.

Type dd 0791 ribotype pattern.

The cell wall peptidoglycan is L-Lys-L-Ala-Gly ${ }_{3}$; the teichoic acid is polyglycerolphosphate- $N$-acetylglucosamine (polyglycerolphosphate substituted by $N$-acetylglucosamine).

The $\mathrm{G}+\mathrm{C}$ content of the DNA is $36.3 \mathrm{~mol} \%$.

Description of Staphylococcus sciuri subsp. rodentium subsp. nov. Staphylococcus sciuri subsp. rodentium (ro.den'ti.um. L. plur. gen. noun rodentium, of rodents). The description below is based on the characteristics of 18 strains isolated in 1992. Colonies grow to $6 \pm 2 \mathrm{~mm}$ in diameter on $\mathrm{P}$ agar and to $10 \pm$ $1 \mathrm{~mm}$ in diameter on TSA. The concentric ridges formed at the edges of colonies are usually higher and wider than the ridges observed in the other subspecies. Growth in the anaerobic portion of semisolid thioglycolate medium ranges from no detectable growth to weak, delayed growth. The optimum growth temperatures are $35^{\circ} \mathrm{C}$ on $\mathrm{P}$ agar and 35 to $40^{\circ} \mathrm{C}$ on TSA. Growth is absent or very poor at $45^{\circ} \mathrm{C}$. Culture growth produces partial hemolysis (greening) of bovine blood. Some strains (39\% of the strains) produce greening of horse blood. All strains produce acid aerobically from D-mannose, D-trehalose, and D-mannitol. Acid is not produced from $\alpha$-lactose. Other characteristics of $S$. sciuri subsp. rodentium that are uniformly positive or negative for the species are listed above. The variable characteristics for this subspecies are listed in
TABLE 5. Characteristics useful for differentiating $S$. sciur subspecies from one another and other members of the $S$. sciuri species group ${ }^{a}$

\begin{tabular}{|c|c|c|c|c|c|}
\hline Characteristic & $\begin{array}{l}\text { S. sciuri } \\
\text { subsp. } \\
\text { sciuri }\end{array}$ & $\begin{array}{l}\text { S. sciuri } \\
\text { subsp. } \\
\text { carnaticus }\end{array}$ & $\begin{array}{l}S . \text { sciuri } \\
\text { subsp. } \\
\text { rodentium }\end{array}$ & S. vitulus & S. lentus \\
\hline P-agar colony diam $\geq 7 \mathrm{~mm}$ & $\mathrm{~d}$ & - & $\mathrm{d}$ & - & - \\
\hline Staph Latex agglutination & - & d & + & + & $\mathrm{d}$ \\
\hline Staph-A-Lex agglutination & - & - &,+ \pm & + & - \\
\hline Alkaline phosphatase activity &,+ \pm & d & $\mathrm{d}$ & - & $( \pm)$ \\
\hline \multicolumn{6}{|l|}{$\begin{array}{l}\text { Acid produced aerobically } \\
\text { from: }\end{array}$} \\
\hline D-Xylose & (d) & + & $\mathrm{d}$ & (d) & $( \pm)$ \\
\hline D-Melezitose & $\mathrm{d}$ & - & d & - & - \\
\hline D-Cellobiose &,+ \pm & $\mathrm{d}$ & $\mathrm{d}$ & (d) & + \\
\hline Maltose & (d) &,+ \pm & (d) & - & $\mathrm{d}$ \\
\hline Raffinose & - & - & - & - & + \\
\hline
\end{tabular}

${ }^{a}+, 90 \%$ or more of the strains are positive;, $\pm 90 \%$ or more of the strains are weakly positive;,, $+ \pm 90 \%$ or more of the strains are positive or weakly positive d, 11 to $89 \%$ of the strains are positive;,$- 90 \%$ or more of the strains are negative. Parentheses indicate that a response is delayed.

Table 3. The two API STAPH-IDENT profiles are $5710(67 \%)$ and $4710(33 \%)$; the major STAPH Trac profile is 6336150 (72\%). The major ribotype pattern type is dd 4761 (75\%). Six different ribotype patterns have been described (Fig. 1). The $\mathrm{G}+\mathrm{C}$ content of the DNA is $35 \mathrm{~mol} \%$. This subspecies is found mainly living on rodent hosts.

Description of the type strain. The type strain of $S$. sciuri subsp. rodentium is DD 4761 (= ATCC 700061$)$, which was isolated from the skin of a Norway rat. It has all of the uniform characteristics of the subspecies described above and, in addition, the properties listed below.

Spherical cells (diameter, 1.0 to $1.2 \mu \mathrm{m}$ ) occur singly, in pairs, and in tetrads.

Circular P-agar colonies are 6 to $7 \mathrm{~mm}$ in diameter, have moderately undulate edges, are raised, are smooth with glistening surfaces, are translucent, and have a light yellow-gray pigment. Colonies on TSA are 9 to $10 \mathrm{~mm}$ in diameter.

Facultatively anaerobic. Delayed weak growth occurs in the anaerobic portion of thioglycolate medium.

Partial hemolysis (greening) of bovine blood occurs. No hemolysis of horse and sheep blood occurs.

No alkaline phosphatase activity and moderate staphylolytic enzyme activity.

Positive latex agglutination test for clumping factor and/or protein $\mathrm{A}$.

Moderate amounts of acid are produced aerobically from D-sorbitol, salicin, D-mannitol, D-trehalose, and D-fucose. Very weak acid is produced from D-cellobiose and maltose. No acid is produced from D-mannose, $\mathrm{L}$-arabinose, $\mathrm{D}$-xylose, $\mathrm{D}$-melezitose, $\alpha$-lactose, and $\alpha$-L-rhamnose.

Intermediate resistance to oxacillin.

Type dd 4761 ribotype pattern.

The cell wall peptidiglycan is L-Lys-L-Ala-Gly ${ }_{3}, \mathrm{~L}-\mathrm{Ser}_{0.1}$; the teichoic acid is polyglycerolphosphate-glucose (polyglycerolphosphate substituted by glucose).

The $\mathrm{G}+\mathrm{C}$ content of the DNA is $35.2 \mathrm{~mol} \%$

Distinguishing characteristics. The phenotypic characteristics that are useful for distinguishing $S$. sciuri subspecies from each other and closely related species are summarized in Table 5. S. sciuri subsp. sciuri can be distinguished from the other subspecies on the basis of its ability to produce acid from D-cellobiose, positive alkaline phosphatase activity, and inability to produce either clumping factor or protein A. S. sciuri 
subsp. carnaticus can be distinguished by its ability to produce acid aerobically from D-xylose and maltose, inability to produce acid from D-melezitose, and generally small colony size on $\mathrm{P}$ agar. S. sciuri subsp. rodentium can be distinguished by its ability to produce a positive reaction in the latex agglutination test for clumping factor and/or protein $\mathrm{A}$ and increased resistance to oxacillin, methicillin, and cefazolin.

\section{ACKNOWLEDGMENTS}

We thank Bill Bowen and V. Thayer (National Marine Fisheries, Beaufort, N.C.) for obtaining bacterial specimens from dolphins and a pilot whale and Herman Berkhoff (College of Veterinary Medicine, North Carolina State University, Raleigh) for assisting in obtaining bacterial specimens from dairy cattle and horses. We also thank Carol George (North Carolina State University) and James Bruce, Eileen Cole, Joe Neubauer, and Channeary Iem McDowell (DuPont Company) for technical assistance.

\section{REFERENCES}

1. Akatov, A. K., V. Hájek, T. M. Samsonova, and J. Balusek. 1985. Classification and drug resistance of coagulase-negative staphylococci isolated from wild birds, p. 125-127. In J. Jeljaszewicz (ed.). The staphylococci. Gustav Fischer Verlag, Stuttgart, Germany

2. Akatov, A. K., and T. M. Samsonova. 1984. Drug resistance of coagulasenegative staphylococci of animal origin depending on the source of the isolation and species classification of the strains. Antibiotiki (Moscow) 29: $117-120$

3. Ames, B. N. 1966. Assay of inorganic phosphate, total phosphate and phosphatases. Methods Enzymol. 8:115-118

4. Anderson, A. J., R. S. Green, and A. R. Archibald. 1977. Specific determination of ribitol teichoic acid in whole bacteria and isolated walls of Bacillus subtilis W23. Carbohydr. Res. 57:C7-C10.

5. Archer, G. L., and E. Pennell. 1990. Detection of methicillin resistance in staphylococci by using a DNA probe. Antimicrob. Agents Chemother. 34 $1720-1724$

6. Ausubel, F., R. Brent, R. Kingston, D. Moore, J. Seidman, J. Smith, and K. Struhl (ed.). 1994. Current protocols in molecular biology. John Wiley \& Sons, New York, N.Y.

7. Bergmeyer, H. U. 1974. Methoden der enzymatischen Analyse. Verlag Chemie, Weinheim, Germany.

8. Brenner, D. J., G. R. Fanning, A. Rake, and K. E. Johnson. 1969. A batch procedure for thermal elution of DNA from hydroxyapatite. Anal. Biochem. 28:447-459.

9. Brosius, J., A. Ullrich, M. A. Raker, A. Gray, T. J. Dull, R. R. Gutell, and H. F. Noller. 1981. Construction and fine mapping of recombinant plasmids containing the rrnB ribosomal RNA operon of E. coli. Plasmid 6:112-118.

10. Bruce, J., W. Kloos, E. Cole, D. Ballard, C. Iem, R. Hubner, and J. Webster. 1994. Variation in Staphylococcus sciuri strains detected by using EcoR fragments containing ribosomal RNA operon sequences and DNA sequence similarities, with recognition of $S$. sciuri rodentius subsp. nov., abstr. R-28, p. 315. In Abstracts of the 94th General Meeting of the American Society for Microbiology 1994. American Society for Microbiology, Washington, D.C.

11. Bruce, J. L., R. J. Hubner, E. M. Cole, C. I. McDowell, and J. A. Webster. 1995. Sets of EcoRI fragments containing ribosomal RNA sequences are conserved among different strains of Listeria monocytogenes. Proc. Natl. Acad. Sci. USA 92:5229-5233.

12. Cole, E., W. Kloos, J. Bruce, D. Ballard, C. Iem, R. Hubner, and J. Webster 1994. Classification of staphylococci by patterns of conserved EcoRI fragments containing ribosomal RNA operon sequences, abstr. R-27, p. 315. In Abstracts of the 94th General Meeting of the American Society for Microbiology 1994. American Society for Microbiology, Washington, D.C.

13. Couto, I., H. de Lencastre, I. Santos Sanches, W. Kloos, and A. Tomasz 1995. Methicillin resistance in Staphylococcus sciuri. Can. J. Infect. Dis. 6(Suppl. C):249C

14. DeHart, H. P., H. E. Heath, L. S. Heath, P. A. LeBlanc, and G. L. Sloan 1995. The lysostaphin endopeptidase resistance gene (epr) specifies modification of peptidoglycan cross bridges in Staphylococcus aureus and Staphylococcus simulans. Appl. Environ. Microbiol. 61:1475-1479.

15. de Lencastre, H., I. Couto, I Santos, J. Melo-Cristino, A Torres-Periera, and A. Tomasz. 1994. Methicillin-resistant Staphylococcus aureus disease in a Portuguese hospital: characterization of clonal types by a combination of DNA typing methods. Eur. J. Clin. Microbiol. 13:64-73.

16. de Lencastre, H., A. M. S. Figueiredo, C. Urban, J. Rahal, and A. Tomasz. 1991. Multiple mechanisms of methicillin resistance and improved methods for detection in clinical isolates of Staphylococcus aureus. Antimicrob. Agents Chemother. 35:632-639.

17. Devriese, L. A. 1990. Staphylococci in healthy and diseased animals. J. Appl. Bacteriol. Symp. Suppl. 69:71S-80S
18. Donham, M. C. H. E. Heath, P. A. LeBlanc, and G. L. Sloan. 1988. Characteristics of extracellular protein production by Staphylococcus simulan biovar staphylolyticus during aerobic and anaerobic growth. J. Gen. Microbiol. 134:2615-2621.

19. Endl, J., P. H. Seidl, F. Fiedler, and K. H. Schleifer. 1983. Chemical composition and structure of cell wall teichoic acids of staphylococci. Arch. Microbiol. 135:215-223.

20. Glauner, B., J. V. Holtje, and U. Schwarz. 1988. The composition of the murein of Escherichia coli. J. Biol. Chem. 263:10088-10095.

21. Hartman, B. J., and A. Tomasz. 1984. Low-affinity penicillin-binding protein associated with $\beta$-lactam resistance in Staphylococcus aureus. J. Bacteriol. 158:513-516.

22. Heath, L. S., H. E. Heath, and G. L. Sloan. 1987. Plasmid-encoded lysostaphin endopeptidase gene of Staphylococcus simulans biovar staphylolyticus. FEMS Microbiol. Lett. 44:129-133.

23. Hubner, R., J. Webster, J. Bruce, E. Cole, J. Neubauer, J. Wyer, R. Betts, J. Banks, T. Bannerman, D. Ballard, and W. Kloos. 1993. Typing of bacteria through the analysis of the ribosomal RNA genes, abstr. R-10, p. 295. In Abstracts of the 93rd General Meeting of the American Society for Microbiology 1993. American Society for Microbiology, Washington, D.C

24. Hubner, R. J., E. M. Cole, J. L. Bruce, C. I. McDowell, and J. A. Webster. 1995. Observed and virtual types of Listeria monocytogenes created by determining the positions of EcoRI cleavage sites relative to rRNA sequences. Proc. Natl. Acad. Sci. USA 92:5234-5238.

25. Kanda, K., K. Hiramatsu, and T. Yokota. 1990. Gel electrophoretic analysi of penicillin-binding proteins of coagulase-negative staphylococci. FEMS Microbiol. Lett. 72:51-54.

26. Kaya, S., Y. Araki, and E. Ito. 1985. Characterization of a novel linkage unit between ribitol teichoic acid and peptidoglycan in Listeria monocytogenes cell walls. Eur. J. Biochem. 146:517-522.

27. Kloos, W. E. 1980. Natural populations of the genus Staphylococcus. Annu. Rev. Microbiol. 34:559-592.

28. Kloos, W. E. Staphylococcus. In L. Collier, A. Balows, and M. Sussman (ed.) Topley \& Wilson's microbiology and microbial infections, 9th ed. vol. 2, in press. Edward Arnold, London, United Kingdom.

29. Kloos, W. E., and T. L. Bannerman. 1995. Staphylococcus and Micrococcus, p. 282-298. In P. R. Murray, E. J. Baron, M. A. Pfaller, F. C. Tenover, and R. H. Yolken (ed.), Manual of clinical microbiology, 6th ed. ASM Press, Washington, D.C

30. Kloos, W. E., and K. H. Schleifer. 1975. Simplified scheme for routine identification of human Staphylococcus species. J. Clin. Microbiol, 1:82-88.

31. Kloos, W. E., and K. H. Schleifer. 1986. Genus IV. Staphylococcus Rosenbach 1884, p. 1013-1035. In P. H. A. Sneath, N. S. Mair, M. E. Sharpe, and J. G. Holt (ed.), Bergey's manual of systematic bacteriology, vol. 2. Williams and Wilkins, Baltimore, Md.

32. Kloos, W. E., K. H. Schleifer, and F. Götz. 1991. The genus Staphylococcus, p. 1369-1420. In A Balows, H. G. Trüper, M. Dworkin, W. Harder, and K. H. Schleifer (ed.), The prokaryotes, 2nd ed. Springer-Verlag, New York, N.Y.

33. Kloos, W. E., K. H. Schleifer, and R. F. Smith. 1976. Characterization of Staphylococcus sciuri sp. nov. and its subspecies. Int. J. Syst. Bacteriol. 26: 22-37.

34. Kloos, W. E., and J. F. Wolfshohl. 1979. Evidence for deoxyribonucleotide sequence divergence between staphylococci living on human and other primate skin. Curr. Microbiol. 3:167-172.

35. Laukova, A. 1994. Antimicrobial susceptibility of ruminal coagulase-negative staphylococci. Microbiologica (Bologna) 17:123-132.

36. Li, Q., and C. L. Ownby. 1993. A rapid method for extraction of DNA from agarose gels using a syringe. BioTechniques 15:976-978.

37. Marmur, J., and P. Doty. 1962. Determination of the base composition of deoxyribonucleic acid from its thermal denaturation temperature. J. Mol Biol. 4:109-118.

38. Matthews, P., and A. Tomasz. 1990. Insertional inactivation of the mec gene in a transposon mutant of a methicillin-resistant clinical isolate of Staphylococcus aureus. Antimicrob. Agents Chemother. 34:1777-1779.

39. Murakami, K., W. Minamide, K. Wada, E. Nakamura, H. Teraoka, and S. Watanabe. 1991. Identification of methicillin-resistant strains of staphylococci by polymerase chain reaction. J. Clin. Microbiol. 29:2240-2244.

40. Nahaie, M. R., M. Goodfellow, D. E. Minnikin, and V. Hájek. 1984. Polar lipid and isoprenoid quinone composition in the classification of Staphylococcus. J. Gen. Microbiol. 130:2427-2437.

41. Neumann, V. C., H. E. Heath, P. A. LeBlanc, and G. L. Sloan. 1993. Extracellular proteolytic activation of bacteriolytic peptidoglycan hydrolases of Staphylococcus simulans biovar staphylolyticus. FEMS Microbiol. Lett. 110: 205-212.

42. Pierre, J., L. Gutmann, M. Bornet, E. Bergogne-Berezin, and R. Williamson 1990. Identification of coagulase-negative staphylococci by electrophoretic profile of total proteins and analysis of penicillin-binding proteins. J. Clin. Microbiol. 28:443-446.

43. Pierre, J., R. Williamson, M. Bornet, and L. Gutmann. 1990. Presence of an additional penicillin-binding protein in methicillin-resistant Staphylococcus epidermidis, Staphylococcus haemolyticus, Staphylococcus hominis, and Staph- 
ylococcus simulans with a low affinity for methicillin, cephalothin, and cefamandole. Antimicrob. Agents Chemother. 34:1691-1694.

44. Robinson, J. M., J. K. Hardman, and G. L. Sloan. 1979. Relationship between lysostaphin endopeptidase production and cell wall composition in Staphylococcus staphylolyticus. J. Bacteriol. 137:1158-1164.

45. Robinson, J. M., H. E. Heath, and G. L. Sloan. 1987. Lack of pleiotropic compensation in extracellular protein production by hypoproducing variants of Staphylococcus simulans biovar staphylolyticus. J. Gen. Microbiol. 133:253257.

46. Rose, K. E., H. E. Heath, and G. L. Sloan. 1985. Simple screening method for identification of nonpleiotropic mutants for exoenzyme production. Appl. Environ. Microbiol. 49:1335-1337.

47. Ryffel, C., W. Tesch, I. Birch-Machin, P. E. Reynolds, L. Barberis-Maino, F. H. Kayser, and B. Berger-Bächi. 1990. Sequence comparison of $m e c A$ genes isolated from methicillin-resistant Staphylococcus aureus and Staphylococcus epidermidis. Gene 94:137-138.

48. Saitoh, Y., A. Shimizu, M. Yagi, T. Adachi, Y. Hikami, J. Kawano, and R. Okamoto. 1993. Isolation and characterization of strains of methicillin-resistant Staphylococcus sciuri isolated from chickens, abstr. V-101, p. 190. In Abstracts of the 115th Meeting of the Japanese Society of Veterinary Science. Japanese Society of Veterinary Science, Tokyo, Japan. (In Japanese.)

49. Sambrook, J., E. F. Fritsch, and T. Maniatis. 1989. Molecular cloning: a laboratory manual, 2nd ed. Cold Spring Harbor Laboratory Press, Cold Spring Harbor, N.Y.

50. Schleifer, K. H., and O. Kandler. 1972. Peptidoglycan types of bacterial cell walls and their taxonomic implications. Bacteriol. Rev. 36:407-477.

51. Schleifer, K. H., S. A. Meyer, and M. Rupprecht. 1979. Relatedness among coagulase-negative staphylococci. Deoxyribonucleic acid reassociation and comparative immunological studies. Arch. Microbiol. 122:93-101.

52. Shimizu, A., J. Ozaki, J. Kawano, Y. Saitoh, and S. Kimura. 1992. Distri- bution of Staphylococcus species on animal skin. J. Vet. Med. Sci. 54:355357.

53. Sloan, G. L., J. M. Robinson, and W. E. Kloos. 1982. Identification of "Staphylococcus staphylolyticus" NRRL B-2628 as a biovar of Staphylococcus simulans. Int. J. Syst. Bacteriol. 32:170-174.

54. Suzuki, E., K. Hiramatsu, and T. Yokota. 1992. Survey of methicillin-resistant clinical strains of coagulase-negative staphylococci for $m e c A$ gene distribution. Antimicrob. Agents Chemother. 36:429-434.

55. Trayer, H. R., and C. E. Buckley III. 1970. Molecular properties of lysostaphin, a bacteriolytic agent specific for Staphylococcus aureus. J. Biol. Chem. 245:4842-4846.

56. Ubukata, K., R. Nonoguchi, M. D. Song, M. Matsuhashi, and M. Konno 1990. Homology of mecA gene in methicillin-resistant Staphylococcus haemolyticus and Staphylococcus simulans to that of Staphylococcus aureus. Antimicrob. Agents Chemother. 34:170-172.

57. Valle, J., E. Gomez-Lucia, S. Pirez, J. Goyache, J. A. Orden, and S. Vadillo. 1990. Enterotoxin production by staphylococci isolated from healthy goats. Appl. Environ. Microbiol. 56:1323-1326.

58. Watts, J. L., and P. J. Washburn. 1991. Evaluation of the Staph-Zym system with staphylococci isolated from bovine intramammary infections. J. Clin Microbiol. 29:59-61.

59. Webster, J. A. T. L Bannerman, R. J. Hubner, D. N. Ballard, E. M. Cole, J. L. Bruce, F. Fiedler, K. Schubert, and W. E. Kloos. 1994. Identification of the Staphylococcus sciuri species group with EcoRI fragments containing rRNA sequences and description of Staphylococcus vitulus sp. nov. Int. J. Syst. Bacteriol. 44:454-460.

60. Woods, G. L., and J. A. Washington. 1995. Antibacterial susceptibility tests: dilution and disk diffusion methods, p. 1327-1341. In P. R. Murray, E. J. Baron, M. A. Pfaller, F. C. Tenover, and R. H. Yolken (ed.), Manual of clinical microbiology, 6th ed. ASM Press, Washington, D.C. 